University of Michigan Law School University of Michigan Law School Scholarship Repository

2016

\title{
In Praise of (Some) Ex Post Regulation: A Response to Professor Galle
}

Kyle D. Logue

University of Michigan Law School, klogue@umich.edu

Available at: https://repository.law.umich.edu/articles/1753

Follow this and additional works at: https://repository.law.umich.edu/articles

Part of the Insurance Law Commons, Law and Economics Commons, and the Torts Commons

\section{Recommended Citation}

Logue, Kyle D. "In Praise of (Some) Ex Post Regulation: A Response to Professor Galle." Vand. L. Rev. En Banc 69 (2016): 97-122.

This Article is brought to you for free and open access by the Faculty Scholarship at University of Michigan Law School Scholarship Repository. It has been accepted for inclusion in Articles by an authorized administrator of University of Michigan Law School Scholarship Repository. For more information, please contact mlaw.repository@umich.edu. 


\title{
In Praise of (Some) Ex Post Regulation: A Response to Professor Galle
}

\author{
Kyle D. Logue*
}

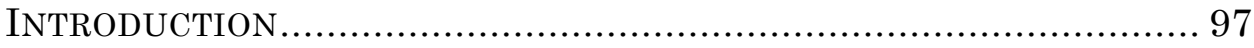

I. IDENTIFYING MARKET FAILURES ................................. 100

II. OPTIMAL REGULATION.................................................. 102

A. Choosing the Optimal Type of Regulation:

Incentive-Based vs. Command-and-Control ........... 102

B. Choosing the Optimal Timing of Regulation:

Ex Ante vs. Ex Post .......................................... 107

III. RESPONDING TO GALLE's ARgument IN FAVOR OF EX

ANTE REGULATION .................................................... 108

A. $\quad$ The Problem of Judgment-Proof Plaintiffs ............ 109

B. $\quad$ The Problem of Unsophisticated and

Cognitively Biased Regulated Parties ................... 110

C. $\quad$ The Political Economy Argument Against Ex Post

Regulation: The Time-Inconsistency Problem ......... 112

D. Galle's Multi-Price Argument: Risk Classification by Another Name................................................ 113

IV. The Role of MANDATORY LIABILITY InSURANCE............. 118

CONCLUSION ...................................................................... 122

\section{INTRODUCTION}

According to modern law-and-economics ("L\&E") orthodoxy, the primary-maybe even the only-legitimate justification for government regulation is to correct a market failure. This conclusion is based on two key assumptions. First, when markets are functioning School.

Wade H. and Dores M. McCree Collegiate Professor of Law, University of Michigan Law 
reasonably well, they are better at achieving efficiency than the government is. ${ }^{1}$ Second, most markets function reasonably well most of the time. Although there is probably evidence to support these assumptions (for example, the relative prosperity of market-based economies in comparison with the relative poverty of centrally planned economies), both assumptions are usually taken as articles of faith by mainstream L\&E scholars. This is why scholarly articles calling for a shift to government-owned means of production or government-provided goods and services are rare. ${ }^{2}$

What remains for debate, then, are questions about which areas in the economy are characterized by market failure and, with respect to those areas, what sort of regulatory response is optimal. Brian Galle's recent essay, In Praise of Ex Ante Regulation, is an excellent treatment of the latter question. ${ }^{3}$ It starts from the assumption that there are market failures to be fixed-externalities of one sort or another-and then focuses primarily on the optimal timing of regulation: whether regulation should generally take effect before the regulated actor's conduct occurs (ex ante regulation) or after the conduct occurs (ex post regulation). ${ }^{4}$ More specifically, Galle argues that ex ante regulation has not been given its due, while ex post regulation has been oversold by some L\&E scholars-including me! ${ }^{5}$

I will have more to say about all of that shortly. But first let me say this: Galle's essay is about more than upending what he calls "a developing consensus" in favor of ex post regulation. ${ }^{6}$ As with Galle's

1. The term "market failure" means something that prevents the market from achieving an efficient outcome. "Efficiency" in this context is synonymous with "Pareto optimality," which is a state of affairs - an allocation of resources-from which no one can be made better off without making someone else worse off. Under conditions of perfect competition (i.e., the total absence of market failures), the first fundamental theorem of welfare economics demonstrates that any competitive equilibrium will be Pareto efficient. HARVEY S. ROSEN \& TED GAYER, PUBLIC FinANCE 40-41 (8th ed. 2008). That a given allocation of resources is Pareto efficient does not mean that it is socially desirable. An efficient allocation of resources can be unjust because it results in unacceptable levels of poverty or inequality. To the extent government policy is designed primarily to help the poor or to reduce inequality, such justifications are generally not put in terms of market failures.

2. One example of an exception is the context of healthcare. A single-payer system is not only supported by many serious healthcare economists in the US, it is the prevailing policy in many developed countries. See List of Countries with Universal Healthcare, TRUE Cost, http://truecostblog.com/2009/08/09/countries-with-universal-healthcare-by-date/

[https://perma.cc/5M46-5X5A] (listing countries with single-payer healthcare systems as of 2013).

3. Brian Galle, In Praise of Ex Ante Regulation, 68 VAND. L. REv. 1715 (2015).

4. Galle, supra note 3, at 1723-24.

5. Id. at 1719 n.20.

6. The actual full quote is this: "My goal is to argue against the developing consensus favoring ex post incentives." Id. at 1719. Notice that Galle uses the term "incentives" in this 
scholarship generally, ${ }^{7}$ the essay provides a wide-ranging and thoughtful analysis of a whole slew of factors-economic, behavioral, political, you name it - that go into choosing the optimal regulatory instrument for a particular situation. Bottom line: the essay is well worth a careful read. What's more, I agree with many of Galle's arguments and conclusions. However, in the interest of scholarly debate, and in the interest of entertaining the reader, I will emphasize our areas of disagreement.

In what follows I offer my own summary of the standard L\&E account of how to choose the optimal policy response to a market failure. The picture of the consensus view on regulation that I paint is somewhat different from the one depicted in Galle's essay. While I agree that there seems to be a consensus in favor of what I call "incentive-based" regulation-what Galle calls "pricing" — there is, so far as I can tell, no consensus among scholars that ex post regulation is generally more efficient than ex ante regulation. Rather, there is at best an argument, which I and others have made, that ex post regulation has certain advantages when particular conditions are present; whereas, in other situations, ex ante regulation is better. And, in many situations, the optimal approach may include some of both. ${ }^{9}$

I also address Galle's three primary arguments against ex post regulation and in favor of ex ante regulation: the liquidity argument (sometimes called the "judgment-proof problem"), the myopia argument, and what I will call the multi-price argument. I conclude that these three arguments, at least the latter two, do not call into question the use of ex post, incentive-based regulation quite to the extent Galle suggests that they do. In fact, I argue that Galle's multiprice argument may actually strengthen the case for ex post regulation of a certain sort.

quote, while he uses the more general term "regulation" in the title of the essay. As I explain below, his essay is really only about the incentives.

7. See, e.g., Brian Galle, The Tragedy of the Carrots: Economics and Politics in the Choice of Price Instruments, 64 STAN. L. REV. 797 (2012).

8. Galle, supra note 3, at 1717. ("It might surprise some readers to learn that for many scholars there is also a good degree of consensus on the best general approach to all these problems. That approach, in a word, is price.").

9. See, e.g., Kyle D. Logue, Coordinating Sanctions in Torts, 31 CARDozo L. Rev. 2313, 2335-43 (2009) (describing various circumstances in which less than "partially" optimizing ex ante agency-based regulation could be efficiently supplemented with tort law as a form of ex post regulation); Jon D. Hanson, Kyle D. Logue, \& Michael S. Zamore, Smokers' Compensation: Toward a Blueprint for Federal Regulation of Cigarette Manufacturers, 22 S. ILL. U. L.J. 519, 528 (1998) (noting that in certain contexts "command-and-control and performance-based regulation might be useful complements to an ex post incentive-based regime"). 


\section{IDENTIFYING MARKET FAILURES}

If regulation is appropriate only when there is a market failure, when exactly is that? For classical economists, the standard answer is when there is an externality of some sort. This occurs when there is an activity that produces costs or benefits not fully borne by the actor engaging in the activity. ${ }^{10}$ Think of the widget maker whose factory emits pollution that harms the environment in some way. Because the widget maker does not bear the cost that the pollution imposes on others (but instead bears only the small fraction of the total cost that the pollution imposes on her), she may invest too little in pollution reduction technology or, underestimating the marginal social cost of widgets, produce too many widgets. Or maybe she will do both: too little care in preventing pollution and too much production. (These are sometimes referred to, separately, as "care level" and "activity level" effects.) ${ }^{11}$ All of this can happen unless there is some form of government regulation that alters the widget maker's incentives, that forces her to take into account the otherwise externalized social costs of her activity. ${ }^{12}$

Markets also fail for reasons other than externalities. As behavioral researchers have documented for decades, human decisionmaking often diverges from the models assumed by classical economists. People are not perfectly rational. ${ }^{13}$ People can be myopic. ${ }^{14}$ They are innumerate. ${ }^{15}$ They give greater weight to losses than they give to gains of equal absolute value. ${ }^{16}$ They regularly exhibit

10. See, e.g., ROSEN \& GAYER, supra note 1, at 46 (defining externalities).

11. Steven Shavell, Economic ANALYsis of ACCIDENT LaW 21 (1987).

12. This conclusion assumes of course that transaction costs prevent the market itself from correcting the externality on its own, through bargaining between victims and injurers. For a general discussion of the problem of transaction costs, see Ronald Coase, The Problem of Social Cost, 3 J. L. \& ECON. 1 (1960).

13. For a highly readable and recent summary of the literature, see DANIEL KAHNEMAN, THINKING FAST AND SLOW (2012). For a summary of some of the implications of behavioral psychology for the economic analysis of law, see Christine Jolls et al., A Behavioral Approach to Law and Economics, 50 STAN. L. Rev. 1471 (1998); Russell B. Korobkin \& Thomas S. Ulen, Law and Behavioral Science: Removing the Rationality Assumption from Law and Economics, 88 CALIF. L. REV. 1051 (2000).

14. See Jolls et al., supra note 13, at 1545 ("People also have bounded willpower; they can be tempted and are sometimes myopic."); Richard Thaler, Misbehaving: The MAKing of BEHAVIORAL ECONOMICS 85-111 (2015) (discussing myopia in terms of lack of self-control).

15. See generally John Allen Paulos, InNumeracy: Mathematical Illiteracy and ITS CONSEQUENCES (explaining and documenting innumeracy).

16. See Daniel Kahneman \& Amos Tversky, Prospect Theory: An Analysis of Decision Under Risk, 47 ECONOMETRICA 263 (1979). 
hindsight bias, ${ }^{17}$ confirmation bias, ${ }^{18}$ and optimism bias. ${ }^{19}$ Their decisions can be significantly affected by how their choices are framed, ${ }^{20}$ by what information is especially salient, ${ }^{21}$ and by their own particular habits of mental accounting for different categories of costs and benefits. ${ }^{22}$ In short, people do not always, or even most of the time, resemble the quintessential Homo economicus of classical economic lore. And that fact-as with the fact of externalities-can be a basis for doubting the efficiency of market outcomes in some settings and hence a justification for regulatory intervention. ${ }^{23}$

The fact that externalities and cognitive biases call into question the efficiency of some market outcomes does not, of course, mean that we should get rid of markets altogether. As mentioned in the Introduction, no one seems to be arguing for switching to a centrally planned economy. Rather, there still seems to be a rebuttable presumption in favor of market-based decision-making over government-based decision-making that goes something like this: unless there is evidence presented suggesting that the externalities and cognitive biases affecting private actors are likely to be worse than the pathologies affecting government actors (such as interestgroup capture or cognitive biases on the part of regulators, who, it turns out, are people too), we should continue to rely primarily on the market to allocate resources. ${ }^{24}$

17. See Baruch Fischhoff, Hindsight $\neq$ Foresight: The Effect of Outcome Knowledge on Judgment Under Uncertainty, 1 J. EXP. PSYCH. 288 (1975).

18. See Raymond S. Nickerson, Confirmation Bias: A Ubiquitous Phenomenon in Many Guises, 2 REV. GEN. PSYCH. 175 (1998).

19. See Shelley Taylor, Positive Illusions: Creative Self-Deception and the HEALTHY Mind (1989).

20. See Amos Tversky \& Daniel Kahneman, The Framing of Decisions and the Psychology of Choice, 211 SCIENCE 453 (1981).

21. See Amos Tversky \& Daniel Kahneman, Judgment Under Uncertainty: Heuristics and Biases 185 SCIENCE 1124 (1974).

22. See THALER, supra note 15 , at 56-83 (discussing framing effects).

23. Some behavioral L\&E scholars organize these various cognitive heuristics and biases into two general categories: "bounded rationality" and "bounded willpower." Jolls et al., supra note 13 , at 1476 . There are numerous examples of laws that can be, and have been, justified on grounds of systematic biases in consumer decision-making-from consumer protection laws in many areas to professional licensing requirements to solvency requirements for financial institutions. To justify consumer protection laws, it is not enough to point out that consumers are uninformed about the consequences of the consumption choices they are making. Even markets comprised of poorly informed consumers can still produce efficient outcomes if consumers are not biased in their decision in one direction or the other. Hence the importance of evidence of systematic biases in human decision-making. Alan Scwartz \& Louis L. Wilde, Intervening in Markets on the Basis of Imperfect Information: A Legal and Economic Analysis, 127 U. PA. L. REV. 630, 640 (1979).

24. There are exceptions to this presumption in favor of markets. Many economists and policy analysts regard health care markets, for example, as different. See, e.g., Jill Horwitz \& 
Why does this presumption exist? Maybe it has to do with the fact that market competition tends to drive out decision-makers who are prone to mistakes or cognitive biases, and it does so in a way that government bureaucracies do not. This is a question that goes well beyond the scope of this essay. In any event, although a full defense of the market presumption is beyond the scope of this Response, it is clearly a presumption upon which much of L\&E scholarship implicitly relies. It also forms the basis of the consensus in favor of incentivebased regulation that, as mentioned, Galle acknowledges.

\section{OPTIMAL REGULATION}

The choice of an optimal policy response to any given market failure can be broken down along a number of dimensions; the two most important are the type of regulation and the timing of regulation. ${ }^{25}$ As to both dimensions, the primary issue involves the extent to which the regulatory instrument relies on market versus government decision-makers. ${ }^{26}$

\section{A. Choosing the Optimal Type of Regulation: Incentive-Based vs. Command-and-Control}

As to the issue of the type of regulation, there has long been a scholarly consensus in favor of what is sometimes called incentivebased or price-based regulation. ${ }^{27}$ With this type of regulation, the regulator's job is to determine the cost of the external harm or the value of the external benefit and then, in effect, to set the "price" for compliance (borne by either the government or the regulated entity,

Helen Levy, Health Care Economics 101 and the Supreme Court, HeAlth AfF. Blog (May 23, 2012), http://healthaffairs.org/blog/2012/05/23/health-care-economics-101-and-the-supreme-court/ [https://perma.cc/EZV5-FEZZ]. Because of the complex and inscrutable nature of the service being provided, we cannot presume that unregulated markets in medical care will lead to efficient outcomes. This is why we regulate who can practice medicine through strict licensure requirements, and why we regulate the provision of medical care in other ways. Many countries, of course, remove the market from medical decisions entirely through the adoption of singlepayer, government-provided health care.

25. Other design elements to be considered include who the primary regulator should be (an agency or a court) and whether the regulation should be government initiated (e.g., SEC enforcement actions) or victim initiated (e.g., civil litigation). Steven Shavell, Liability for Harm Versus Regulation of Safety, 13 J. LEGAL STUD. 357, 361-64 (1984).

26. Id.

27. See Jon D. Hanson \& Kyle D. Logue, The Costs of Cigarettes: The Economic Case for Ex Post Incentive-Based Regulation, 107 YALE L.J. 1163, 1263-81 (1998) (summarizing literature on incentive-based regulation). 
depending on the type of externality) equal to that amount. ${ }^{28}$ This is done through some sort of tax (for negative externalities) or subsidy (for positive externalities). ${ }^{29}$ Why is there a scholarly consensus in favor of regulation by price in most situations? ${ }^{30}$ In comparison with other types of policy instruments, incentive-based regulation relies more heavily on market forces and private decision-making than do other types of regulation.

To see this point, focus on the contrast between incentive-based regulation and so-called command-and-control regulation in the context of negative externalities. A command-and-control approach to regulation requires the regulator not only to determine the nature and extent of the negative externality caused by the activity in question, but also the precise regulatory response that is most efficient-that minimizes the negative externality at lowest cost to the externalizing party and to society generally. ${ }^{31}$ Thus, the command-and-control regulator must decide precisely how-which technologies to deploy-to reduce a given negative externality. This imposes an enormous informational burden on the regulator. ${ }^{32}$ For example, the regulator must know not only the amount and nature of the harm caused by the externality, but also the cost and efficacy of every possible approach to reducing that harm.

With incentive-based regulation, by contrast, the regulator needs to know only the marginal social harm caused by the regulated

28. This tax, sometimes referred to as a Pigouvian tax, is levied on each unit of output "in an amount just equal to the damage [that output] inflicts at the efficient level of output." ROSEN \& GAYER, supra note 1 , at 82 (8th ed. 2008).

29.

It might surprise some readers to learn that for many scholars there is also a good degree of consensus on the best general approach to all these problems. That approach, in a word, is price. Many scholars believe government should do its best to make sure that the price market actors face in making their decisions accurately reflects all the society-wide costs and benefits of those decisions. That accomplished, government should then step back and let the market work.

Galle, supra note 3, at 1717.

30. Below I discuss circumstances in which other types of regulation may be superior to incentive-based regulation.

31. Robert W. Hahn, Economic Prescriptions for Environmental Problems: How the Patient Followed the Doctor's Orders, 3 J. ECON. PERSP. 95, 95 (1989) (describing command-and-control regulations an approach in which the "regulator specifies the technology a firm must use to comply with regulations").

32. Bruce A. Ackerman \& Richard B. Stewart, Reforming Environmental Law, 37 STAN. L. REV. 1333, 1337 (1985) ("Such determinations impose massive information-gathering burdens on administrators, and provide a fertile ground for complex litigation in the form of massive adversary rulemaking proceedings and protracted judicial review."). 
party's activity. ${ }^{33}$ The regulator does not need to know anything about the costs or benefits of alternative solutions to the externality. That information is in effect provided by the market. Going back to the widget-making-polluter example, once the regulator sets a price (through a tax or fine) to force the widget maker to internalize the otherwise externalized marginal social cost of its pollution, competition among widget makers (and between widget makers and other potential users of the widget makers' resources) creates incentives for optimal investment in widget production and in the reduction of widget-factory pollution. And after the widget maker takes all cost-internalizing steps to respond to the incentive-based regulation, if widget purchasers are not willing to pay the higher costinternalized price for widgets, then widget makers will eventually get the signal, and widget factories will be converted to some non-widgetmaking use that does not produce so much pollution or that produces more social value to offset its pollution. Or, if widget purchasers so love their widgets that they are willing to pay the cost-internalized price, thus allowing widget makers to continue making a profit, such a result implies that widget factories must be producing sufficient social benefits to justify their total social costs, including the pollution.

A similar, almost symmetrical story can be told for incentivebased subsidies of positive externalities. If some activity produces benefits to society that are not fully internalized by the decisionmaker, the regulator offers a monetary subsidy equal to the value of that external benefit. In such a case, once the beneficial externality has been internalized, the market can be relied upon ${ }^{34}$ to produce the most efficient overall outcome. So, for example, if businesses tend to underinvest in research and experimentation that benefit society generally, an ideally designed incentive would be set to approximate the marginal social benefit of each dollar invested in research and experimentation. And all of the specific choices about how best to respond to this new incentive-this new negative price for investing in R\&D—would be left to the market.

In sum, incentive-based regulation addresses market failures by forcing companies to internalize the cost (or the benefit) of a given externality and then allowing the "corrected" market to determine how resources will ultimately be allocated. Contrast this picture with

33. This is not necessarily an easy thing to know. Recall, that the optimal regulatory tax must be set based on the marginal harm at the efficient level of production. See ROSEN \& GAYER, supra note 1 , at 82 .

34. When I say "can be relied upon," it's not that I, or anyone else, think markets are perfect. It is only that, in the absence of identified market failures, markets generally are thought to be better at allocating resources in society than government agencies. 
a command-and-control, also sometimes referred to as "standard setting," approach to regulating negative externalities. ${ }^{35}$ A commandand-control regulator in effect replaces market-based decision-making entirely with government-based decision-making. ${ }^{36}$ For example, a command-and-control regulator in our widget-making example might require the widget manufacturer to install Technology $X$ in all of its factories in order to minimize pollution in the most cost-justified manner. For such a regulatory mandate to be efficient, however, the regulator must take into account all of the relevant costs and benefits and determine that a given amount of investment in Technology $X$ is the most efficient response to the pollution externality in question. To reach that conclusion, the regulator would need to know not only the social costs of widget manufacturing (which, as mentioned, the incentive-based regulator would also need to know), but also the costs and benefits of Technology $X$ as well as the costs and benefits of every other alternative pollution reduction response, including other technological innovations as well as the response of simply reducing production. With incentive-based regulation, again, these determinations are made by the market though the interaction of supply and demand. ${ }^{37}$

Just because command-and-control regulation is difficult to implement effectively and requires a great deal of information on the part of the regulator, however, does not mean that it is never the best regulatory instrument. ${ }^{38}$ To the contrary, there are plenty of situations in which specific regulatory mandates, despite the difficulty of getting them right, may be optimal. This is true, for example, when a regulator determines that certain actions are efficient for all or almost all regulated parties. Examples of this might include the requirement that all workplaces meet certain minimal safety standards (e.g., electrical wiring, sprinkler system, number of exits) or that all new automobiles come with certain safety features included (seatbelts and

35. See Michael G. Faure, Environmental Regulation, in 2 ENCYCLOPEDIA OF LAW AND ECONOMICS 452-53 (Bouckaert \& De Geest eds, 2000).

36. Id. ("When lawyers refer to standards, they usually refer to the regulatory measures, usually used and imposed by administrative agencies, that prescribe what measures a factory causing an externality should take to prevent harm."). The classic article explaining the virtues of government set prices, via taxes, to regulate externalities, as compared with other types of regulatory control, is William J. Baumol \& Wallace E. Oates, The Use of Standards and Prices for Protection of the Environment, 73 SwEDISH J. ECON. 42 (1971).

37. See Hanson \& Logue, supra note 27, at 1264-65 (explaining the nature of and extent of the information that a regulator must have to do command-and-control regulation properly).

38. Wallace E. Oates et al., The Net Benefits of Incentive-Based Regulation: A Case Study of Environmental Standard Setting, 79 AM. ECON. REV. 1233 (1989) (noting that incentive-based regulation is not always superior to command-and-control regulation). 
airbags, for example). Likewise, it might be efficient to simply ban certain products that have been deemed too dangerous under any circumstances to be sold (e.g., metal tipped lawn darts, Bucky Balls, trans fats $)^{39}$ or to ban certain activities considered too dangerous to be engaged in by anyone (riding a motorcycle without a helmet, discharging a firearm within the city limits)—or by anyone other than a licensed professional (law, medicine, structural engineering). As these examples illustrate, command-and-control regulation works especially well to provide a given "floor" of protection from certain negative externalities - or, in the case of positive externalities, a floor of investment in public goods. ${ }^{40}$

The distinction I have been describing between incentive-based regulation and command-and-control regulation is, of course, a false dichotomy. Many types of regulation have elements of both. For example, cap-and-trade environmental regulation is often considered a type of incentive-based regulation because of its reliance on private markets to determine how best to reduce certain types of emissions. But cap-and-trade also has command-and-control elements, insofar as the environmental regulator must decide on the amount of the cap, a decision that requires just the type of information that a commandand-control regulator would need. Moreover, incentive-based and command-and-control regulation can work together, for example, in the context of safety regulation. In some situations, it might make sense for the regulator to set a minimal floor of safety while the same or another regulator also imposes ex post fines or damages for harms caused. Indeed, such coordination of ex ante, command-and-control regulation and ex post, incentive-based sanctions can be seen in the context of prescription drug risks, where federal drug safety standards

39. Gary S. Becker \& Richard A. Posner, Uncommon Sense: Economic Insights, From MARRIAGE TO TERRORISM 139-42 (2009) (arguing that New York city's ban of trans fat, the most extreme form of command-and-control mandate, is defensible on the ground that the harm of trans fat, in terms of health cost, clearly and greatly exceeds the social benefits). Lawn darts were banned in 1988 by the Consumer Product Safety Commission (CPSC) because of their extreme riskiness. News Release, CPSC Votes Final Ban on Lawn Darts (Oct. 28, 1988), http://www.cpsc.gov/en/Newsroom/News-Releases/1988/CPSC-Votes-Final-Ban-On-Lawn-Darts/ [https://perma.cc/FD8V-DDEE]. More recently, the CPSC banned the sale of Buckyballs magnetic toys. Ian Simpson, CPSC Bans Sale of Buckyballs Magnetic Toys, Cites Hazard, REUTERS (July 25, 2012), http://www.reuters.com/article/us-usa-buckyballsidUSBRE86O1LN20120725 [https://perma.cc/N7E7-EQ3D].

40. See Logue, supra note 9 (discussing agency command-and-control regulations in terms of floors). Government funding for public schools can be thought of as a sort of command-andcontrol subsidy for K-12 education, where the government provides not only the subsidy but the rules about how the public good should be provided. By contrast, publicly funded school vouchers would be more of an incentive-based version of the subsidy. 
are enforced ex ante by the Food and Drug Administration, and state products liability standards are enforced ex post by the courts. ${ }^{41}$

\section{B. Choosing the Optimal Timing of Regulation: Ex Ante vs. Ex Post}

In addition to the type of regulation, a choice must be made about timing. Ex ante regulation is implemented before the external harm or benefit actually happens, usually around the time that the important economic decisions are being made. Ex post regulation, by contrast, is implemented after the external harm or benefit happens, which can be months or years later.

Consider the widget factory example again. Under an ex ante, incentive-based approach to regulating widget-factory pollution, the regulator must estimate how much harm each unit of widget production will cause in the future, discount that amount to account for both the probability that the harm will in fact occur (assuming there is some probabilistic element) and the passage of time, and then assess that tax against the polluter. Such ex ante cost-internalizing sanctions are sometimes referred to as "Pigouvian" taxes. ${ }^{42}$ Under the ex post version of this regulation, the regulator does nothing until the pollution actually causes harm-if it ever does-which could be years in the future. At that point, either the regulator determines who caused the harm and imposes a fine, or, characterizing tort law as regulation, a court does so at the behest of a complaining victim or class of victims. Either way, the polluter must pay the amount of the harm after the fact, and only if the harm occurs.

Under either regime, the negative externality is efficiently internalized if everything works perfectly. Under the ex ante tax, the widget maker is forced to consider the external harm its product process causes, as she will in effect have to write a check to the regulator as each widget is produced. Under the ex post fine or damages approach, the regulation is somewhat less direct: the widget maker, knowing that if its production process causes harm to the environment it will be required to pay for that harm, is forced to consider those costs ex ante. Ideally the effects are exactly the same.

41. This coordination requires a determination as to whether the federal regulatory standards will preempt state tort law. For a discussion of how that determination should be made from the perspective of choosing the optimal combination of policy instruments, see generally $i d$.

42. A Pigouvian tax, sometimes spelled "Pigovian" tax, is named after Nobel-winning economist Arthur C. Pigou, who is credited with the idea of cost-internalizing taxes. ROSEN \& GAYER, supra note 1, at 82; Victor Fleischer, Curb Your Enthusiasm for Pigovian Taxes, 69 VAND. L. REv. 1673, 1675 (defining Pigovian taxes); see also ARThur C. Pigou, The Economics OF WELFARE, 192-93 (4th ed.1932). 
But the world is not ideal, and each approach has strengths and weaknesses.

The strength of ex post approach is that it asks less of the government regulator. This is so in the following sense: the regulator-whether it is an agency or a court-must determine the extent of the harm caused by the regulated party's activity only after the harm has occurred. This is the point in time when determining the amount and nature of the harm is presumably easiest; it is a task mostly of measurement and not of prediction. By contrast, the ex ante pollution regulator must make a guess about how much harm will happen, to whom, and when-not to mention choosing a discount rate, which can be controversial. This difference is what scholars mean when they say that ex post regulation has an "informational advantage" over ex ante regulation. ${ }^{43}$

Note, however, that ex post regulation asks more of the regulated party than does ex ante regulation. Instead of relying upon the regulator to determine the appropriate regulation ex post, the regulated party must decide what to do ex ante. All regulation, in a sense, gets implemented ex ante when the relevant behavioral decisions are made. And under ex post regulation, while it is the regulator who will make regulatory decisions after the fact, it is the private market actors who must make the educated guesses ex ante about what the consequences of their actions will be, what steps to take to minimizes harms and maximize benefits, and so on. Not so, with ex ante government regulation, where the government agency must make ex ante predictions about future harms or benefits.

\section{RESPONDING TO GALLE'S ARGUMENT IN FAVOR OF EX ANTE REGULATION}

The two primary advantages of ex ante regulation are, unsurprisingly, the two weaknesses of ex post regulation, at least in the context of negative externalities. These are the judgment-proof problem and the problem of unsophisticated (or biased) regulated parties. Galle uses both of these problems to argue against ex post regulation and in favor of ex ante regulation. ${ }^{44}$ In addition, Galle suggests a political economy argument for why ex post regulation may be inferior to ex ante regulation. This section addresses these three arguments in turn.

43. See Galle, supra note 3, at 1728 n.58 (summarizing the relevant literature).

44. See infra notes 45 and 48. 


\section{A. The Problem of Judgment-Proof Plaintiffs}

As many other scholars have done before (including me), Galle rightly points out that one serious problem with ex post regulation, whether in the form of fines or tort damages, is the so-called judgment-proof problem. ${ }^{45}$ Ex post, incentive-based regulation of negative externalities works only insofar as the regulated party has assets sufficient to cover the costs of whatever harm her activity might cause. To the extent the potential harm threatened by the regulated party's activity exceeds that party's assets, the difference will be externalized, despite the threat of ex post sanction. That is, the widget maker who faces the possibility of a $\$ 200$ million fine for any harm her product causes, but who has only $\$ 30$ million at stake in the business, will take into account the threat of the fine only to the extent of her $\$ 30$ million of assets. In other words, the widget maker will externalize around $\$ 170$ million of the risk that her activity creates. This phenomenon, sometimes called the judgment-proof problem (Galle calls it the "liquidity concern"), ${ }^{46}$ does not undermine the deterrence effects of ex ante fine in the same way, because such a fine can be much smaller, owing to the effects of probability discounting. Similarly, ex ante, command-and-control regulation does not succumb to the judgment-proof problem, as mandates can usually be enforced irrespective of the amount of size of the regulated party's assets.

To see this point, now let's imagine that the widget-making process does not produce pollution, but that widgets themselves, when used by consumers, will on very rare occasions explode so violently as to cause death or serious bodily injuries to the consumer and to any unlucky bystanders. Specifically, assume that each widget sold poses a 1 in 100,000 chance of producing a $\$ 10$ million harm. Under an ex post liability regime, if such a harm occurs, the company will be required to pay $\$ 10$ million in damages to the victims or their families. How the company will perceive this threat of liability depends on the value of the assets the company expects to own at the time the ex post sanction will be imposed. If the company expects to have $\$ 10$ million or more in assets, it will ex ante perceive the threat of liability to constitute an expected cost of $\$ 100$ (1/100,000 multiplied by $\$ 10$ million). If, however, the company expects to have only $\$ 2$ million in assets when

45. Galle, supra note 3, at 1738-43 (discussing liquidity problem, which is another term for judgment-proof problem, and "limited liability companies," which are a special case of the judgment-proof problem). Galle discusses some of my work on the judgment-proof problem at note 4 and notes 37-39, and again around notes 96-101.

46. Steven Shavell, The Judgment Proof Problem, 6 InT'L. REv. L. \& Econ. 45, 45-46 (1986) (outlining the "judgment proof" problem); Galle, supra note 3, at 1738. 
the damages are assessed, it will perceive the threat of liability to constitute an ex ante cost of only $\$ 20$ (1/100,000 multiplied by $\$ 2$ million). This is what is meant by the judgment-proof problem.

Contrast this scenario with the incentives created by an ex ante tax or fine of equivalent expected value. If a regulator, instead of imposing ex post liability, were to impose an ex ante tax of $\$ 100$ on the company's activity, the company would internalize the full $\$ 100$ of social cost, even if the company the company has only $\$ 2$ million in assets. Indeed, this will be true whatever amount of assets the company has, so long as that value, net of all other expenses, exceeds the amount of the tax. Thus, the ex ante fine/tax would be internalized despite the judgment-proof problem in a way that the ex post fine would not.

Command-and-control regulation can work in such a judgmentproof setting, for much the same reason. If the regulator decides that the company should make a per-unit investment of $\$ 75$ in safety Technology $Z$ to reduce the risk of harm caused by widgets, the regulator can simply command the company to do just that or else suffer a punitive penalty of $\$ 100$ or $\$ 10,000$ or an amount equal to all of the company's profit-whatever is large enough to induce the additional safety investment. Such a command can work even if the $\$ 10$ million of harm risked by the company's activity exceeds the value of the company's assets.

These are good reasons to prefer either ex ante incentive-based regulation or ex ante command-and-control regulation to ex post regulation. Or, as discussed further below, they are reasons optimal regulation will often entail some of both—or even all three.

\section{B. The Problem of Unsophisticated and Cognitively Biased Regulated Parties}

In addition to the judgment-proof problem, ex ante regulation may be preferable to ex post regulation in settings where the regulator is likely: (a) to have better access to information about the future consequences of the regulated parties' actions, (b) to know more about what steps the regulated party should take to maximize social benefits and minimize social harms, and (c) to be more likely to make rational decisions with all of that information.

All three of these factors might apply if the regulated party is someone other than a sophisticated commercial actor operating in a competitive market. Consider, for example, Average Joe Driver or Mom-and-Pop Business Owners. These are individuals who, though their activities pose significant risks to others, are not fully aware of 
the nature of magnitude of that risk. Or, they might not be fully informed of the ways in which they could minimize that risk.

Average Joe, for example, drives a car which has the capacity at any moment to cause serious physical injuries or death to other drivers or pedestrians, as well as property damage to other cars. Joe is of course generally aware of these risks, but he may have no idea of the precise size of those risks or how much those risks can be affected by what seem like minor changes in his driving behavior. Similarly, Mom and Pop may be relatively good at their business-running a smallish, roadside hotel-but they may not fully understand the potential societal cost of their failure to invest in a modern fire-safety system with smoke and heat sensitive automatic sprinklers.

By contrast, the regulatory authorities tasked with regulating auto safety and local fire codes likely have much better information about all of these factors. If that is true, then ex post regulation, which depends for its justification on the relative expertise of private parties compared with regulators, may not work as well as ex ante regulation, even if there is no judgment-proof problem. This is one reason we impose speed limits on drivers and command-and-control safety mandates on businesses. The threat of ex post sanctions for failing to drive reasonably or failing to install minimal safety measures in one's place of business may not induce optimal care levels or activity levels, if the regulated parties simply do not know (and find it too costly to learn) what optimal behavior looks like, or if the regulated parties are more likely (than the regulator) to suffer from the sorts of cognitive biases discussed above, including myopia and optimism bias.

It should be emphasized, however, that this relative information-cost/cognitive-bias story may favor ex post regulation over ex ante regulation in some situations. Specifically, when the regulated parties are sophisticated commercial entities that are likely to know more about the risks of their activities than the government does, and where those parties have sufficient assets sufficient to cover the risks they pose (neutralizing the judgment-proof problem). In these cases, there is a relatively strong case for ex post, incentive-based regulation, either alone or in combination with various forms of ex ante regulation. This might be true, for example, in the context of products liability as applied to large, consumer product manufacturers. ${ }^{47}$

47. For an argument that big tobacco presents a relatively strong case for ex post incentivebased regulation, see Hanson \& Logue, supra note 27 at 1273-78. For a more general argument in favor of strict products liability, see Jon D. Hanson \& Kyle D. Logue, The First-Party Insurance Externality: An Economic Justification for Enterprise Liability, 76 CORNELL L. REV. 129, 164-70 (1990). 
One of the more interesting arguments in Galle's defense of ex ante regulation can be understood as a response to the argument just made. That is, Galle emphasizes a particular sort of myopia that can lead even large corporate entities, perhaps especially large corporate entities, to underestimate or systematically ignore the likelihood of an ex post sanction. ${ }^{48}$ It is well known that, because of the separation of ownership and control in such businesses, corporate managers can make decisions that are not necessarily in the best long-term interests of their shareholders. ${ }^{49}$

As Galle points out, this type of agency problem can pose special problems in the context of ex post regulation if the corporate managers expect not to be around when the ex post sanction is imposed. In such a case, the managers have the same ex ante incentive to externalize the threat of that sanction as a much smaller regulated party-one who is judgment-proof or more prone to cognitive biases. This is indeed a serious limitation on ex post regulation and an argument for ex ante regulation, as even the myopic executive would find it difficult to ignore a direct regulatory command or an ex ante Pigouvian tax. Below in Part IV, I suggest how mandatory liability insurance might be a potential solution, and I address Galle's concerns about this solution.

\section{The Political Economy Argument Against Ex Post Regulation: The Time-Inconsistency Problem}

Galle also identifies another potential problem with reliance on ex post regulation: some regulated parties are likely to lobby effectively to eliminate ex post sanctions before they can be imposed. ${ }^{50}$ This concern, like the agency-problem concern, would apply primarily to large corporate regulated parties. While the government may adopt a policy of ex post sanctions with the best of intentions, when the time comes to impose those sanctions, the regulator may find it very difficult politically to carry through with this policy plan. As a result, the government's initial commitment to impose ex post sanctions may not be credible, thus undermining the ex ante incentive effect of such a policy instrument. ${ }^{51}$

48. Galle, supra note 3, at 1743-44.

49. The classic citation for this point is Eugene F. Fama \& Michael C. Jensen, The Separation of Ownership and Control, 26 J. L. \& ECON. 301, 305 (1983).

50. Galle, supra note 3, at 1734-36.

51. Id. For a general discussion of the difficulties that governments often face in trying to make credible commitments to particular policy plans over time, see Finn E. Kydland \& Edwin C. Prescott, Rules Rather than Discretion: The Inconsistency of Optimal Plans, 85 J. PoL. ECON. 
One potential solution to this "time-inconsistency" problem, in the context of ex post regulation, is for the government to create a permanent, institutionalized, ex post compensation regime. Such a regime would resemble a workers' compensation program or the federal vaccine compensation program-or, for that matter, a system similar to American products liability law ${ }^{52}$-all of which impose damages or taxes on the regulated parties after the fact to fund compensation payments to those harmed by the regulated activity. ${ }^{53}$ The key to neutralizing the time-inconsistency problem is that the damages payments under such a regime must be assessed automatically upon a showing by the injured victim that he or she has been harmed, with no need for lawmakers to vote on additional appropriations. It is the opportunity to revisit the original choice of a "policy path" that creates the time-inconsistency problem.

Adopting such a permanent compensation regime would not only eliminate the need for a new vote on potentially politically sensitive new taxes, it would also create a large and influential interest group that would counteract the political influence of the regulated parties. Indeed, the very fact that tort law, workers' compensation law, and a number of other such compensation/regulatory regimes exist (and have not been eliminated despite the active lobbying of the regulated parties) suggests that this pre-commitment problem for ex post regulation highlighted by Galle may not be insuperable. ${ }^{54}$

\section{Galle’s Multi-Price Argument: Risk Classification by Another Name}

To my mind the most interesting argument that Galle makes in favor of ex ante regulation and against ex post regulation is what $\mathrm{I}$ call his multi-price argument, and it goes something like this: One of the purported advantages of ex post over ex ante, incentive-based

473, 486-87 (1977). For a discussion of how this so-called time-inconsistency problem creates issues for legal transitions, see Kyle D. Logue, Tax Transitions, Opportunistic Retroactivity, and the Benefits of Government Precommitment, 94 MicH. L. REV. 1129, 1142-43 (1996).

52. But see infra discussion about the possible administrative-cost advantages of the workers' compensation approach compared with traditional tort law.

53. Saul Levmore and I made essentially this same argument, in the context of terrorism compensation and crime arrangements, in Saul Levmore \& Kyle D. Logue, Insuring Against Terrorism-And Crime, 102 MicH. L. REv. 268, 291-95 (2003).

54. I agree with Galle, though, that reliance on ad hoc government compensation programs, such as FEMA disaster relief, can create non-optimal incentives. Galle, supra note 3, at 1736-37. Indeed, Omri Ben-Shahar and I have made precisely this argument. See generally Omri Ben-Shahar \& Kyle D. Logue, The Perverse Effects of Subsidized Weather Insurance, 68 STAN. L. REV. (forthcoming 2016). 
regulation is that the price set by the regulator is more likely to be accurate in the former case than in the latter. Again, the government regulator-whether it be an agency or a court-will have more information after the harm occurs and will reach a relatively more accurate assessment of individualized harm caused to the particular victims and by the particular injurers. By contrast, a regulator setting the price ex ante will typically lack the information necessary to set individualized prices. As a result, the best that the ex ante regulator can do is to set a single price for all regulated parties at a level that minimizes the sum of deadweight losses associated with the errors in measurement. 55

To see this point, consider a very simple example involving tort law. Imagine that a widget is a consumer product that poses a nontrivial risk of harm (a very small likelihood of a very serious injury) to individuals who purchase and use it. Assume further that widgets can be designed several different ways and that some of the designs pose a greater risk of injury to widget users than others. Now, assume initially that a federal agency tasked with regulating widget-injury risks decides to implement an ex ante Pigouvian tax. Specifically, the agency opts to impose on widget makers a per-unit tax equal to the social marginal external harm associated with widgets. Because of information constraints, however, assume for now that the regulator is only able to determine the average per unit injury risk of widgets. As a result, the most accurate ex ante Pigouvian tax the regulator can manage is one that is equal to the mean of per-unit social harm associated with all widgets in the market.

The problem with this industry-average ex ante Pigouvian tax is the inevitable over- and under-pricing. For widget makers selling safer-than-average widgets, the industry-average tax is too high; for those selling riskier-than-average widgets, the industry-average tax is too low. The resulting errors of both types produce deadweight loss, in the sense that some people are overpaying for unsafe widgets and underpaying for safe ones. ${ }^{56}$ This disparity also creates inefficient incentives for widget makers, as the sellers of relatively safe widgets are induced by the industry-average tax to cut spending on safety,

55. Louis Kaplow \& Steven Shavell, Fairness Versus Welfare, 114 HARV. L. REv. 961, 125356 (2001).

56. The two types of errors do not offset each other. Likewise, if the weather outside is way too hot in the day and way too cold at night, one does not conclude that, because the average temperature was moderate, the weather overall was pleasant. 
thereby externalizing the extra widget risk onto the other manufacturers paying the tax. ${ }^{57}$

If we put to one side the judgment-proof and biased-regulatedparty problems discussed above, an ex post system of regulation, in theory, solves the mispricing problem caused by an industry-average tax. If we assume that each widget maker will be held liable ex post for the injuries caused by its particular widgets, all widget makers, foreseeing that possibility, will have an incentive to invest in costeffective safety enhancements, since they will reap the full reward of such expenditures through the lower expected costs of ex post damage claims. Meanwhile, widget makers who skimp on safety will be punished. For the same reason, the optimal number of widgets will be purchased, as the price of each widget will reflect its full expected ex post liability cost.

Not so fast, Galle says. Besides the fact that the judgmentproof problem and myopic-regulated-parties do exist, the ex ante regulator is not necessarily limited to a single industry-average price. If the ex ante regulator has just a little more information, it can organize the regulated parties into a few groups (or "clusters," to use Galle's term) based on their risk-relevant characteristics and then set group-based or cluster-based prices/taxes. ${ }^{58}$ By doing so, the regulator can reduce the sum of overall deadweight losses from the regulated activity. As Galle puts it:

[F]or each individual, the deadweight loss caused by government mispricing is a function of the distance between the price that individual faces and the marginal social benefit of correcting the externality. Under multiple prices, the government can in effect divide up the population and assign members to the price that is closest to them, thereby diminishing deadweight loss. ${ }^{59}$

Galle makes the point several different ways, including mathematically. ${ }^{60}$ But you can see the basic point through my simple example. Instead of charging the same Pigouvian price to all widget makers, imagine that the ex ante regulator is able to group all widget makers into, say, three categories, based on the safety of their widget designs: the makers of "very safe" widgets, the makers of "moderately safe" widgets, and the makers of "borderline unsafe widgets." The

57. Indeed, if this hypothetical ex ante widget tax were continually updated based entirely on the means of all widgets, adverse selection would create a tendency for all widget makers eventually to cut spending on safety, and the market for safe widgets would begin to unravel. There may be a limit to the unraveling, assuming consumers have some ability to perceive the riskiness of widgets. Put differently, consumers' demand for, and ability to perceive, the safety in their widgets might serve as the floor in terms of how far safety unraveling might go.

58. Galle, supra note 3, at 1730 .

59. Id.

60. Id. at 1731 n.68. 
member of each group would then be charged the (otherwise externalized) mean per-unit widget risk for that group.

There would still be some variance within each group, and thus some over- and under-charging. But if the risk clusters or risk groups are accurately assembled, the sum of the errors within each group (and the size of the resulting safety disincentive) would be less than the sum of the errors (and safety disincentive) under the industrywide single tax. If, however, it is difficult for the regulator to sort the widget makers into the appropriate risk group, and easy for the widget makers to misrepresent which group they belong in, there would be a problem. If lots of borderline-unsafe widget makers are taxed as if they were very-safe widget makers, then segregating all of the widget makers into these risk groups could actually make matters worse, increasing rather than decreasing the total over- and underpricing. Putting that distressing possibility to one side, if we are willing to let ex ante regulators set more than one price based on clusters of regulated parties, Galle argues, ex ante incentive-based regulation can at least in theory be more efficient than people have recognized. ${ }^{61}$

Further, Galle argues that the tendency of some forms of ex post regulation to create fully individualized incentives for each regulated party, as described in the hypothetical above, may also not be optimal. ${ }^{62}$ For example, the tort system-with its long, expensive discovery process, its complex trials with additional live testimony, and its ultimate jury determination, all designed to determine the precisely accurate ex post sanction in each case-may be inefficiently "overinvesting in precision." 63 What is needed, Galle seems to be arguing, is incentive-based regulation that imposes multiple prices on regulated parties but not too many prices. ${ }^{64}$

Note, however, that there are countervailing forces that push in the direction of using more individualized ex post prices than Galle's argument implies. Specifically, there are efficiency advantages (that Galle ignores) associated with an ex post regulatory regime that not only creates ex ante regulatory incentives but also serves to

61. Id. at 1720-21; see also Kaplow \& Shavell, supra note 55.

62. Galle, supra note 3, at 1734 ("Infinite price flexibility" may not be optimal "especially in a world with some observational error. With more price categories, it is easier for the government to mistakenly assign a producer to the wrong price point.").

63. Id. ("Regimes such as the tort system, which are built to match price exactly to each defendant, may be wastefully over-investing in precision.”).

64. Id. at 1733-34 (after noting that three prices in his simulation produced only a quarter of the deadweight loss caused by a single price, observing that "[t]hese results also imply that infinite price flexibility is not optimal"). 
compensate the victim of the regulated parties' actions. That is, if we assume that it is efficient to provide compensation for harms caused through some form of insurance (because people tend to be risk averse), there are efficiency gains that Galle's analysis overlooks if the compensation arrangement can be designed so that it simultaneously produces ex ante regulatory incentives. Every dollar spent on accurately assessing how much the victim was harmed serves two functions: it serves an insurance function by determining how much the injured victim optimally should receive; and it serves a regulatory function by determining how much the injurer should have to pay.

Having said all of that, I nevertheless concur with the general conclusion that, even where ex post incentive-based regulation is the most efficient regulatory tool, there is a decent case for adopting a system that produces somewhat less individually tailored sanctions (or damages) than does the traditional tort system in the United States. In setting up any system of regulation and compensation, there is an unavoidable tradeoff between adjudicative accuracy and administrative cost; and the U.S. tort system may well lean too far in the direction of the former at the expense of the latter. ${ }^{65}$ This conclusion is a primary justification for a number of alternative compensation regimes that have been adopted in various contexts, such as workers' compensation regimes at the state level and the National Vaccine Injury Compensation Program at the federal level. ${ }^{66}$

Such alternative compensation schemes streamline the adjudicative process, and thereby lower administrative costs, by collecting claimants into groups (or clusters) based on a relatively simple set of characteristics (everyone with a particular category of injury gets a particular amount of compensation); they also provide greater certainty to regulated parties since the payment schedules for particular injuries are fixed. Such regimes, by reducing the highly individuated awards found in the traditional tort system, have a regulatory effect similar to what Galle is arguing for: more than a single price, but not "infinite price flexibility." Moreover, such regimes could potentially be put to greater use than is currently the case in other areas of tort law, for example, with respect to the injury risks associated with autonomous vehicles. ${ }^{67}$

65. Louis Kaplow, The Value of Accuracy in Adjudication: An Economic Analysis, $23 \mathrm{~J}$. LEGAL STUD. 307 (1994).

66. See generally Hanson, Logue, \& Zamore, supra note 9, at 536-44 (summarizing those programs).

67. See, e.g., Kevin Funkhouser, Paving the Road Ahead: Autonomous Vehicles, Products Liability, and the Need for a New Approach, 2013 UTAH L. REV. 437, 460-62 (discussing, as 
I should also note that, even under current tort law, liability insurance produces an effect very similar to what I have just described and similar to what Galle is arguing for in terms of ex ante grouping into regulatory clusters. I discuss that phenomenon in the next Part.

\section{THE ROLE OF MANDATORY LIABILITY INSURANCE}

As I (with others) have argued elsewhere, liability insurance, in addition to shifting and spreading risk, serves the function of converting the threat of ex post sanctions into ex ante premiums that roughly reflect the risks being insured. ${ }^{68}$ Moreover, liability insurance companies have an incentive to adjust their premiums to reflect the risks accurately. Why? Because if they fail to do so, they can lose customers to more aggressive insurers, or the insureds may opt to self insure. Liability insurance, then, can be understood as a form of private risk regulation with insurance premiums being, in effect, market-based, ex ante regulatory taxes. ${ }^{69}$

There are limits, however, on the ability of insurance to regulate behavior. As Galle points out, insurers face various frictions. ${ }^{70}$ For example, some state regulators impose limitations on the prices that insurers can charge. Moreover, insurers suffer from externality problems of their own as an industry. For example, to the extent an insurer's investments in risk-reduction technology benefits its competitors, there is a free-rider problem that undermines the incentive to make such investments. ${ }^{71}$ In general, the interests of insurance companies do not perfectly coincide with society's interests. Their goal, after all, is to make a profit, not minimize risk. However, this profit motive does provide a motivation that government regulators do not have. Moreover, insurers, because of the nature of their business, have access to information that regulators typically lack. ${ }^{72}$ For these reasons, the combination of ex post government sanctions with liability insurance coverage (and the resulting

alternative to traditional tort system for future market in driverless cars, a regime based on model of vaccine compensation regime).

68. Hanson \& Logue, supra note 27; Ben-Shahar \& Logue, supra note 54.

69. See Omri Ben-Shahar \& Kyle D. Logue, Outsourcing Regulation: How Insurance Reduces Moral Hazard, 111 Mich. L. REV. 197, 217 (2012).

70. Galle, supra note 3, at 1739 ("The insurance industry . . . is not frictionless and perfectly informed.").

71. Ben-Shahar \& Logue, supra note 69, at 229-31 (discussing externalities that might undermine insurers' incentive to price risks in manner that is socially efficient from a deterrence perspective).

72. Id. at $218-19$. 
differential, ex ante insurance premiums) seems like a promising alternative or supplement to ex ante government regulation.

But liability insurance cannot serve this regulatory function in the presence of the judgment-proof problem, the problem of unsophisticated regulated parties, and the myopia problem discussed above, unless regulated parties are required to purchase coverage. The judgment-proof problem, for example, undermines the incentive to purchase liability insurance in the first place. Parties have little incentive to purchase liability insurance in excess of their assets, and we have the same problem if the risk of their activities is substantially greater than their assets. ${ }^{73}$ Moreover, if actors systematically underestimate certain risks, again perhaps because of their myopia, they may not be willing to pay the actuarially fair premium to purchase coverage. For these reasons, liability insurance can serve its regulatory function fully only if the government mandates coverage in amounts approximating the actual risk posed by the regulated activity. ${ }^{74}$

Government mandates of liability insurance coverage are, of course, a form of ex ante regulation. But the ex ante regulation is limited to mandating the purchase of liability insurance. Under such a mandate, in contrast with the sort of ex ante, incentive-based regulation that Galle touts, it is insurance companies-as they compete for profits - that set the optimal, risk-reducing prices ex ante, rather than the regulator. If we believe that private insurance companies, because of their relatively superior access to accident-loss data and their profit motives, are better able to set such prices than government agencies, then mandatory liability insurance is a superior form of ex ante regulation-or combination of ex post and ex ante regulation-than the sort of purely agency-based price setting Galle prefers.

Note also that liability insurance mandates would make insurance companies not only the private regulators of risk, but also the gatekeepers to the regulated activity in question. Some might regard this as unappealing or politically implausible. In situations in which no insurance company is willing to provide coverage for a particular activity for a particular insured, are we really prepared to treat that outcome as an outright ban on that party's ability to engage in the activity? In the context of automobile insurance, which is one of the few areas in which we currently have mandatory liability insurance, the answer seems to be no. Indeed, most states create

73. Shavell, supra note 46 .

74. Id. 
special insurance pools to provide coverage for drivers that private markets are not willing to insure. ${ }^{75}$

But perhaps the auto-insurance example suggests a way in which mandatory insurance can work together with ex ante government price setting. ${ }^{76}$ To the extent we believe that the outcome produced by mandatory liability insurance is too harsh-perhaps because there are beneficial externalities or distributive justice concerns that insurance markets do not take into account-direct, ex ante subsidies can be provided to make insurance affordable. This can be done while maintaining at least some of the marginal deterrent effect provided by premium differentials in liability insurance, which may be superior to an alternative that relies solely on ex ante government price setting.

Still, the critiques described above do qualify the extent to which insurance can help overcome the judgment-proof problem, and to that extent they undermine the case for ex post regulation. How significant those critiques are in practice, however, is not clear. At least in circumstances in which the regulated parties are large commercial entities, whose assets are sufficient to cover most of the risks of their activities, ex post regulation may still be superior to ex ante regulation. Likewise, ex post regulation may be superior in those domains in which we are willing to mandate full liability insurance coverage or where parties, even in the absence of government mandates, tend to carry sizeable amounts of coverage for one reason or another. ${ }^{77}$

75. For example, the California Assigned Risk Plan creates a "residual pool" of drivers who were not able to get coverage from private auto insurers in conventional markets. The plan requires each auto insurer operating in California to take a share of those high risk drivers and provide them with coverage. See California Automobile Assigned Risk Plan, ValuePenguin, http://www.valuepenguin.com/auto-insurance/california/assigned-risk-plan [https://perma.cc/ 72L2-WFHQ] (last visited Mar. 28, 2016) (discussing California Automobile Assigned Risk Plan). Most states have such a plan. See Plan Sites, AIPSO, https://www.aipso.com/PlanSites.aspx [https://perma.cc/6A6E-5LGA] (last visited Mar. 28, 2016) (providing links to states with auto assigned risk plans).

76. Another prominent, and somewhat infamous, example of mandatory insurance can be found in the Affordable Care Act's minimum essential coverage provision, also known as the "individual mandate." 26 U.S.C. 5000A(a) ("An applicable individual shall for each month beginning after 2013 ensure that the individual, and any dependent of the individual who is an applicable individual, is covered under minimum essential coverage for such month."). In my view, however, that particular insurance mandate is better understood not as a regulatory provision designed to internalize costs, but rather as sort of revenue-raising tax designed to fund a public good. See Kyle D. Logue, NFIB v. Sebelius and the Individual Mandate: Thoughts on the Tax/Regulation Distinction (Univ. of Mich. Public Law Research Paper No. 498, 2016), http://papers.ssrn.com/sol3/papers.cfm?abstract_id=2741471 [https://perma.cc/J433-L7WE].

77. Galle also expresses doubt that mandatory liability insurance would correct the judgment-proof or myopia problems. Galle, supra note 3, at 1746 ("In my view, the available 
Finally, let's return to Galle's multi-price argument in favor of government ex ante price-setting over ex post regulation coupled with liability insurance mandates. Recall Galle's argument that if government regulators can set regulatory prices at more than one price under ex ante government price-setting, they can produce more efficient regulatory incentives than can be produced either by a single industry-wide price or by the infinitely flexible pricing that characterizes the traditional tort system of ex post damages. ${ }^{78}$ They can cluster regulated parties into groups, according to their relative risks, and charge prices according to the mean of the group. ${ }^{79}$ This cluster pricing will produce most of the deterrent benefit of individualized pricing, which is the model of ex post regulation that Galle imagines, where courts set individualized ex post prices on all injury causing conduct-a result that Galle suggests is much more expensive than it is worth. ${ }^{80}$

Here, I want to point out that such cluster pricing is precisely what insurance companies do, and they have been doing it for many years. When insurers underwrite risks, they gather information about clusters (they call them "pools") of insureds who represent roughly similar liability risks, and then they charge everyone within the pool roughly the same premium. Moreover, insurers engage in exactly the sort of optimization strategy that Galle recommends, classifying risks only up to the point where the marginal benefits of doing so equals the marginal costs. Thus, liability insurers, as I've pointed out, function to convert ex post sanctions into ex ante regulations. The resulting set of prices approximates better than any real world example of an ex ante,

evidence suggests that insurers would not, in fact, be able to effectively sensitize managers to future costs."). His primary argument relies on the fact that commercial lenders do not currently take steps to encourage their borrowers to behave in ways that reduce the risk of large ex post judgments or fines, even though lenders are supposedly in the same economic position from a regulatory perspective as a liability insurer would be. $I d$. I disagree that lenders are in the same position as liability insurers. Lenders must take into account many different factors that play into the risk of nonpayment of a loan, including how well the company's business is doing, how well the economy is doing, and so on. The possibility of a bankrupting tort case is a fairly small dot on the radar screen. For the liability insurer, however, their only job is to cover such cases, and their only interest, especially once they've collected the premium, is in reducing the risk of such tort claims. My research in his area suggests that insurers in fact do quite a bit to try to encourage their insureds to minimize their liability risk. See generally Ben-Shahar \& Logue, supra note 54, at 199 ("This Article develops the claim that in a variety of areas private insurance companies can, and already do, replace or augment the standard setting and safety monitoring currently performed by government.").

78. Galle, supra note 3, at 1729-34.

79. Id.

80. Id. 
Pigouvian tax-the sort of efficient, ex ante regulatory tax that Galle and many others envision.

\section{CONCLUSION}

The risks to life, health, and property that merit regulation present complex problems for which the best regulatory response is often not a single regulatory tool, but rather a combination of regulatory instruments. Among the regulatory instruments that can be effective is the ex post, incentive-based approach, which often takes the form of tort law or some other compensation-based regime or some other type of ex post government-imposed sanction.

This type of regulation will be most useful, relative to ex ante forms of regulation, where either: (a) the regulated parties themselves are both solvent (or, at least, not judgment-proof) and relatively free from various cognitive and political biases, or (b) the regulated parties either voluntarily purchase full liability insurance or are mandated to purchase such coverage. In either situation, ex post regulation can harness private information and market forces to induce regulated parties to internalize costs that would otherwise be externalized.

This is not to say that, even in these contexts, there is not room for ex ante government regulation beyond insurance mandates. In fact, there are situations where government access to information is simply better than that of even the largest, most sophisticated commercial actors. Moreover, there may be situations in which the private incentives of insurance companies and those of society more generally will diverge. Ex ante regulation obviously has an important role to play in those situations. 